\title{
EXPERIMENTAL AND SIMULATION STUDIES OF OXY-FUEL COMBUSTION FOR CARBON CAPTURE AND SEQUESTRATION (CCS) FROM A COAL/BIOMASS POWER PLANT
}

\author{
Nelia Jurado, Hamidreza G. Darabkhani*, Edward J. Anthony, and John E. Oakey \\ Institute for Energy and Resource Technology (IERT), School of Applied Sciences, Cranfield University, \\ Cranfield, Bedfordshire MK43 OAL, UK \\ ${ }^{*}$ Corresponding Author: h.g.darabkhani@cranfield.ac.uk
}

\begin{abstract}
Oxyfuel combustion is one of the major carbon capture technologies, and a very promising technique to facilitate $\mathrm{CO}_{2}$ Capture and Sequestration (CCS) for new and existing coal/biomass-fired power plants. In this research experimental and simulation oxy-combustion trials are carried out at Cranfield University by co-firing mixtures of pulverised coal and biomass using a 100kW retrofitted oxy-combustor. The parent fuels are coal (Daw Mill) and biomass cereal co-product (CCP) and experimental work was done for $100 \%$ coal $(\mathrm{w} / \mathrm{w}), 100 \%$ biomass $(\mathrm{w} / \mathrm{w})$ and a blend of coal $50 \%(\mathrm{w} / \mathrm{w})$ and biomass $50 \%(\mathrm{w} / \mathrm{w})$. The recirculation flue gas (RFG) rate was set to be of $52 \%$ of the total flue gas. The maximum percentage of $\mathrm{CO}_{2}$ observed was $56.7 \%$ wet-based $(73.6 \%$ on a dry basis) when $100 \%$ Daw Mill coal was fired. Major and minor emissions species and gas temperature profiles were obtained and analysed for different fuel mixtures. A drop in the maximum temperature of more than $200 \mathrm{~K}$ was observed when changing the fuel from 100\% Daw Mill coal to 100\% cereal co-product biomass. Deposits formed on the ash deposition probes were also collected and analysed using the Environmental Scanning Electron Microscopy (ESEM) with Energy Dispersive X-ray (EDX) technique. The high sulphur, potassium and chlorine contents detected in the ash generated using $100 \%$ cereal co-product biomass are expected to increase the corrosion potential of these deposits. In addition, a rate-based simulation model has been developed using Aspen Plus $\circledast$ and validated by comparison with the experimental results. It is concluded that the model provides an adequate prediction for the gas composition of the flue gas.
\end{abstract}

\section{INTRODUCTION}

Oxy-fuel combustion is one of the main options for the capture of $\mathrm{CO}_{2}$ from fossil fuel-fired power generation. Oxyfuel combustion has several characteristics which make it a very attractive technology to implement in both existing air-firing and new power plants. These include, generation of a stream of flue gas with a high percentage of $\mathrm{CO}_{2}$ which is easy to be captured, reduction in the size of the flue gas conditioning equipment, no additional space required for the post combustion capture equipment and also reduced environmental impacts compared with other carbon capture technologies (Corsten et al., 2013).

The main disadvantage of oxy-fuel combustion technology is the efficiency loss and elevated cost associated with generating high-purity $\mathrm{O}_{2}$ by cryogenic separation. Nonetheless, oxy-firing remains an extremely promising option as it requires minimal modification of existing coal-fired plants, and for coal-firing at least it can already be considered to be near commercial technology. This is, however, not the case for co-firing with biomass. Such studies that have been done on co-firing of coal and biomass (Arias et al., 2008 ; Toftegaard et al., 2010) have noted that the ignition temperature decreases as the proportion of biomass in the fuel increases. It is found that the fuel burnout improves when oxy-firing blends of coal and biomass (Arias et al., 2008 ; Smart et al., 2010a ; Borrego et al., 2009). Recycling the flue gas to the oxy-combustor decreases the NO content (reduced or reburnt) and SOx emissions (S is retained in the ashes) per energy unit of fuel combusted (Smart et al., 2010b) and (Toftegaard et al., 2010) suggested that boiler corrosion problems are likely to appear as the acid gases increase in the flue gases, as compared with the air-firing case. They (Toftegaard et al., 2010) also pointed out the problems that are likely to appear during the utilization of the cement or concrete fabricated with the fly ashes generated in the oxy-combustion process, due to the higher content of SOx retained in them. It is, therefore, clear that while much is known, more research is required on a wide range of biomass fuels co-fired with coal in oxy-fuel systems. Ideally, experimental programs should be supported by process modelling so the results of such tests can be generalized and used to provide data on scale-up.

Typical commercial packages used to support experimental studies or model full-scale systems include Fluent, Chemkin Pro, Aspen Plus $\AA$, gPROMS, Thermoflex or Hysis. However, prior to the use of this software to study combustion processes, such as conventional combustion, fluidised circulating bed combustion, and oxy-firing, rigorous research was undertaken on the characterisation of char combustion (Field, 1969 ; Murphy and Shaddix, 2006). Researchers who have investigated the oxy-firing process using Aspen Plus $₫$ include (Sotudeh-Gharebaagh et al., 1998) and circulating fluidised bed using coal as fuel in air-firing conditions (Xiong et al., 2011), and (Hu and Yan, 2012), both using coal as fuel in oxy-firing assuming equilibrium conditions. However, to date few authors have performed simulations on oxy-firing for co-firing using Aspen Plus $\AA$. The work endeavours to fill this gap, by providing such an experimental study using a $100 \mathrm{~kW}$ unit, together with a simulation of co-firing coal and biomass blends. The rate-based simulation model was designed to predict the gas composition and temperatures reached in the oxy-combustion mode, albeit with the simplifying assumptions proposed by (Edge et al., 2011). 
The multi-fuel combustor rig at Institute for Energy and Resource Technology (IERT) in Cranfield University comprises both a fluidised bed (50 kWth) and a down-fired pulverised fuel combustor (100 kWth). For the oxycombustion tests here, only the pulverised fuel combustor (PF) was used, with the gate valve, placed between the fluidised bed (FB) and the PF, closed to isolate the fluidised bed section of the reactor (see Fig. 1).

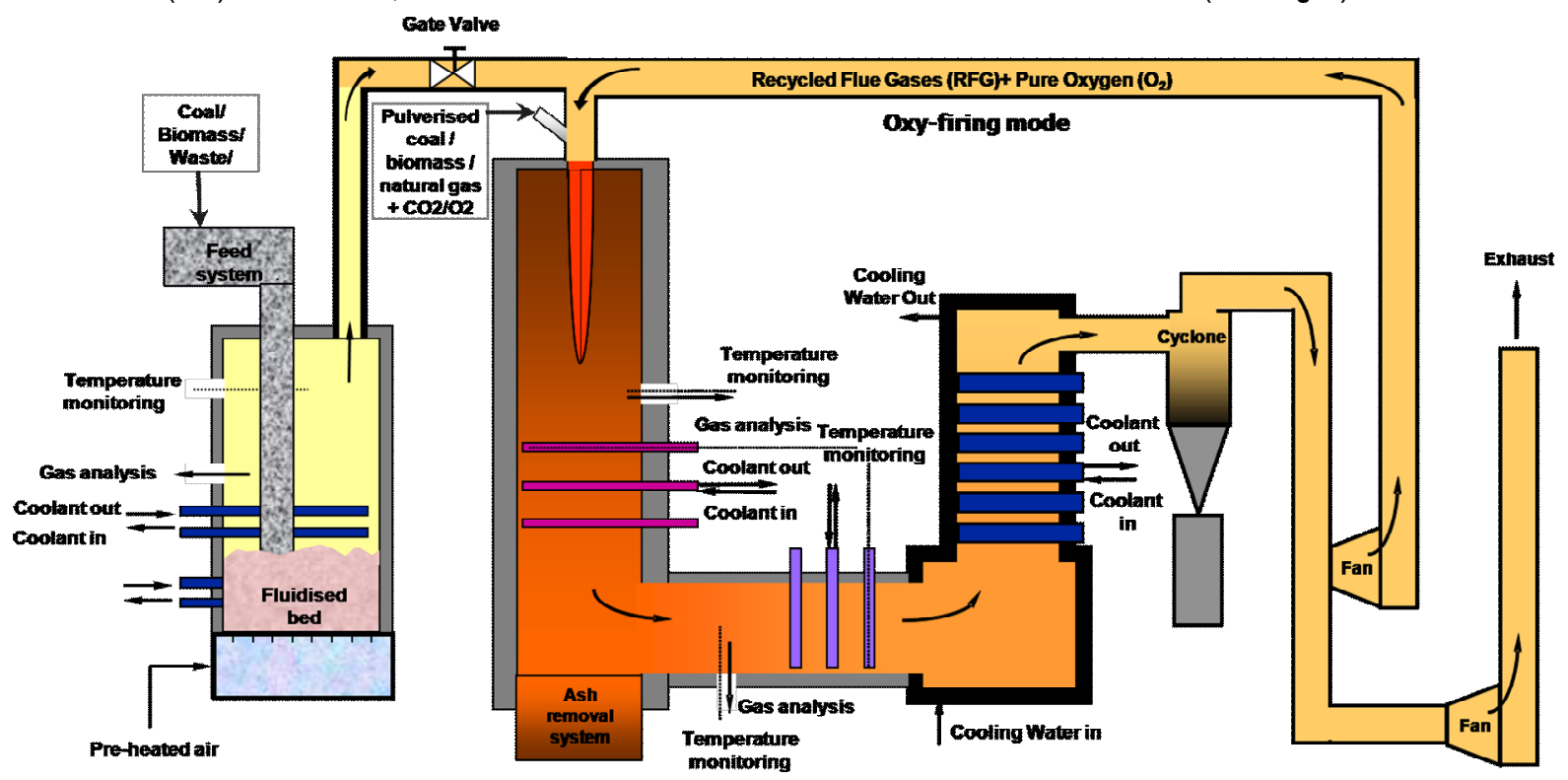

Fig. 1 Diagram of Multi-fuel Combustion Rig at IERT including the RFG pipe for the oxy-firing mode

The pulverised fuel is fed to the oxy-combustor at a constant rate using a fuel feeder provided by a metering screw, a vibratory tray and a venturi eductor. Additionally, the feeder has three purge points located: at the main storage hopper, at the feeding hopper, and at the end of the vibratory tray feeder). $\mathrm{CO}_{2}$ is injected through these purge points to keep a positive pressure inside the pulverised fuel feeding system so as to avoid air ingress once the pulverised fuel reaches the venturi eductor, it is fluidised and conveyed to the burner by a stream of pure $\mathrm{CO} 2$ gas coming from $\mathrm{CO}_{2}$ cylinders. Prior to this stream being fed to the burner, the primary $\mathrm{O}_{2}$, coming from $\mathrm{O}_{2}$ cylinders, is also injected into the primary stream.

The combustor is equipped with a down-fired burner, provided with a pilot flame port and a flame detector. The pulverised fuel is combusted in the vertical zone of the combustor ( $3.7 \mathrm{~m}$ height). The combustor has a square cross-section with sides of $650 \mathrm{~mm}$ and thermal isolation with thickness $175 \mathrm{~mm}$. The vertical zone has four view ports and ports where sensors are used to measure wall temperatures (six type $\mathrm{K}$ thermocouples). The data acquisition system is a Pico Logger Unit-TC-08. More thermocouples are installed along the rig-monitoring: inlet and outlet temperature of the water used in the refrigeration system, at the heat exchanger section, temperature after the cyclone, and six more thermocouples to measure the temperature along the recirculation line. These sensors are sampled using the data logger, with 24 sampling ports distributed along the vertical and horizontal sections of the chamber. Three of these ports, placed at the bottom part of the vertical section, are used by the deposition probes. To collect the deposits, it was necessary to allow the chamber to cool down for 18 to $24 \mathrm{~h}$, then the ash deposited on the probes was sampled and analysed using ESEM/EDX. An on-line high-resolution multi-component Fourier Transform Infra-red (FTIR) gas analyser is connected to one of the aforementioned sampling ports located at the vertical section of the chamber to measure the composition of the oxy-combustion gas.

The exhaust gas goes through two water-cooled heat exchangers, one in the horizontal and one in the vertical section, before exiting the oxy-combustor. Finally, after leaving the chamber, the gas enters a cyclone where the suspended particles are removed. Then part of the gas is recirculated to the combustion chamber and the rest is sent to the stack. The pipelines that convey the recycled flue gas are thermally isolated with a trace heating system to avoid a temperature drop below the acid dew point of the flue gas. The secondary $\mathrm{O}_{2}$ is injected into this stream prior to feeding it to the oxy-combustor.

The PF oxy-combustor at IERT is based on a retrofit to the existing air-firing combustor. The retrofitting process involved the installation of the recirculation line including setting up the recirculation fan, the $\mathrm{O}_{2}$ injection to the recycle flue gas (secondary $\mathrm{O}_{2}$ ) and trace heating wiring to prevent condensation in the flue gas recirculation lines. Additionally, a line to supply the $\mathrm{CO}_{2}$ was installed to convey the pulverised fuel from the hopper to the burner itself. The second phase covered the design and fitting of an axial swirler in the air inlet port of the burner; the implementation of a gas-tight fan to recirculate the flue gas; the primary $\mathrm{O}_{2}$ injection, added to the stream conveying the fuel to the combustor; installation of the gas-tight fuel-feed hopper; and the design and replacement of a new $\mathrm{CO}_{2}$ supply line, to respond to the design requirements of the new fuel feeder.

For these tests $100 \%$ coal (w/w), $100 \%$ biomass (w/w) and blend of coal $50 \%(\mathrm{w} / \mathrm{w})$ and biomass $50 \%(\mathrm{w} / \mathrm{w})$ were used. The coal used was Daw Mill and the biomass was cereal co-product (CCP) the analyses of which are shown in Table 1. 
Table 1. Analysis of Daw Mill and Cereal Co-Product (CCP)

\begin{tabular}{|c|c|c|}
\hline Properties & Daw Mill & CCP \\
\hline \multicolumn{3}{|c|}{$\mathrm{CV}, \mathrm{kJ} / \mathrm{kg}$ (as received) } \\
\hline -Gross & 25260 & 17610 \\
\hline$-\mathrm{Net}$ & 24107 & 16340 \\
\hline \multicolumn{3}{|c|}{ Proximate analysis $(\%(w / w))$} \\
\hline - Moisture & 4.6 & 8.1 \\
\hline - Fixed carbon & 62.78 & 18.39 \\
\hline - Volatile matter & 32.8 & 77.04 \\
\hline - Ash & 4.4 & 4.57 \\
\hline \multicolumn{3}{|c|}{ Ultimate analysis $(\%(w / w))$} \\
\hline$-\mathrm{C}$ & 77.7 & 47.22 \\
\hline$-\mathrm{H}$ & 4.5 & 6.46 \\
\hline$-\mathrm{N}$ & 1.2 & 3 \\
\hline$-\mathrm{Cl}$ & 0.2 & 0.18 \\
\hline$-S$ & 1.3 & 0.17 \\
\hline$-\mathrm{O}$ & 10.9 & 38.4 \\
\hline \multicolumn{3}{|c|}{ Sulphur analysis $(\%(w / w))$} \\
\hline - Pyritic & 0.2 & 0.06 \\
\hline -Sulfate & 0 & 0.05 \\
\hline - Organic & 1.1 & 0.06 \\
\hline
\end{tabular}

The experiments have been carried out with recirculation of $52 \%(\mathrm{v} / \mathrm{v})$ flue gas to the oxy-combustor. Calculations have been carried out for the cases in which the $\mathrm{O}_{2}$ would be fed to the process at a $5 \%, 10 \%$ and $21 \%(\mathrm{v} / \mathrm{v}$ ) excess. The results of the calculations are presented in Table 2. To ensure safe conditions for the oxygen injection, the oxygen percentage in the primary stream must not exceed $21 \%(\mathrm{v} / \mathrm{v})$. For the secondary stream, which is mainly comprised of the recycled flue gas, the upper limit for the oxygen content is $28 \%$. These limits are selected to ensure that the oxygen leaving the combustor varies between 3 and $5 \%(\mathrm{v} / \mathrm{v})$. The operating pressure in the combustor must be below atmospheric pressure due to design conditions. However, to minimise the air ingress into the chamber, the pressure during the experimental tests was kept as close as possible to atmospheric pressure.

\section{SIMULATION APPROACH}

Limited publications are available giving the results of oxy-combustion of blends of coal and biomass considering the kinetics for the char combustion, and this paper seeks to explore these issues further. In the model suggested here, a number of reactors have been defined to recreate as faithfully as possible the experimental process. The main effort has been focused on providing a mathematical model of the reactor where the char particles are oxy-fired. Furthermore, an equation has been proposed to provide the kinetics in the oxy-combustor. Additional reactors have been included in the model to simulate the gas treatments (particle removal and desulphurisation) before the recirculation of the flue gas to the combustor or its proceeding to the next stage of the carbon capture process $\left(\mathrm{CO}_{2}\right.$ purification and compression).

The implementation of the model presented in this paper has been carried out using Aspen Plus® V7.3 and has taken place in two stages. A model based on the equilibrium of the reactions was first defined. The aim of this stage was to perform an initial analysis of the resulting mass and energy balances, providing an assessment of the contribution of different inputs including: percentage of oxygen excess; percentage of recycled flue gas (RFG); heat loss in the RFG stream; and air ingress into the process. The equilibrium model was developed taking into account published work (Xiong et al., 2011 ; Hu and Yan, 2012), and Aspen Plus® tutorials/guidelines. In the second stage, a kinetic model was developed. The additional output of this model provides a more realistic approach to the process than the equilibrium one. The criterion adopted here is to ensure the same heat transfer as in the air-firing case (Wall et al., 2009). However, this paper focuses on the explanation of the kinetic simulations, as noted in the introductory section.

The oxy-combustor is simulated using five reactors: the first one to convert the fuel, nonconventional solid, to a conventional one; a reactor to perform the combustion of the volatile species of the fuel; a reactor to simulate the combustion of the char; a reactor where the thermal NOx is generated; and lastly, a reactor to simulate the generation of NOx from the $\mathrm{N}$ of the fuel. A variation of the previous case study was considered, in which an additional block was implemented to simulate the partial condensation of $\mathrm{H}_{2} \mathrm{O}$ vapour during recirculation of the flue gas to the oxy-combustor. This set of simulations was necessary so as to have a kinetic model with operating conditions as similar as possible to the experimental tests performed in the pilot plant. The box-plot for the ratebased case is presented in Fig. 2.

In the next stage a rate-based model with partial condensation will be developed for dry recirculation modelling. To define the amount of $\mathrm{H}_{2} \mathrm{O}$ vapour that condenses in this reactor, the vapour pressure of the $\mathrm{H}_{2} \mathrm{O}$ at the minimum 
temperature reached in the flue gas will be considered. This value established the maximum concentration in the gaseous phase that the $\mathrm{H}_{2} \mathrm{O}$ vapour could have. Thus, if the $\mathrm{H}_{2} \mathrm{O}$ vapour concentration is higher, it will condense.

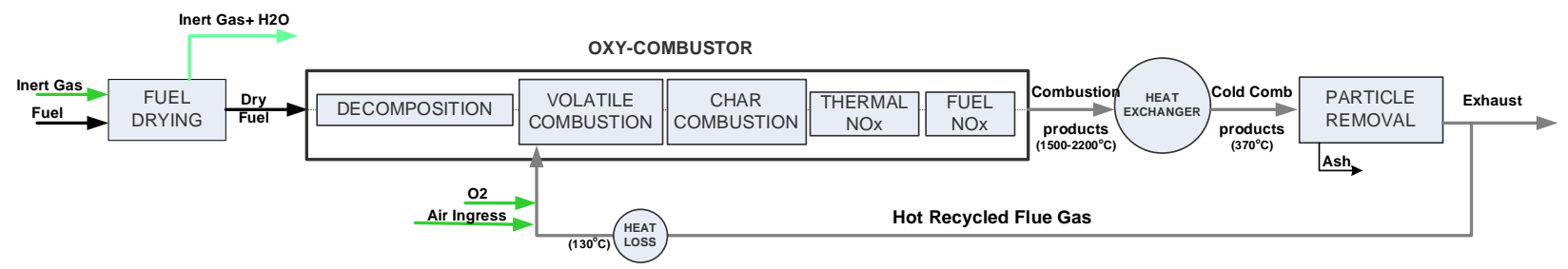

Fig. 2. Box- plot of the Rate-based Model.

The methodology adopted to compare results from simulations and experimental data was, first, to set up operating conditions as similar as possible to the experiments; and second, to perform the simulations comparing the results generated by the model in Aspen Plus ${ }^{\circledR}$ regarding gas composition and temperatures reached. For the first step (establish similar operating conditions), it was necessary to find out the amount of air ingress into the process which occurred during the experiments. This was accomplished using mass balances based on the experimental data. In addition air ingress was varied in the model, until analogous values generated by the simulations to the empirical gas composition were obtained. Although the air ingress is an unknown variable that needed to be characterised, other operating parameters were changed in the simulations to find out the combination that best represented the experimental conditions during the tests. These parameters were: percentage of RFG, excess of oxygen fed, and amount of water vapour condensed.

\section{RESULTS AND DISCUSSION}

\section{Experimental Results}

The emissions of gaseous species using different fuels (100\% coal, $100 \%$ biomass, and $50 \%$ coal-50\% biomass) are shown in Fig. 3.
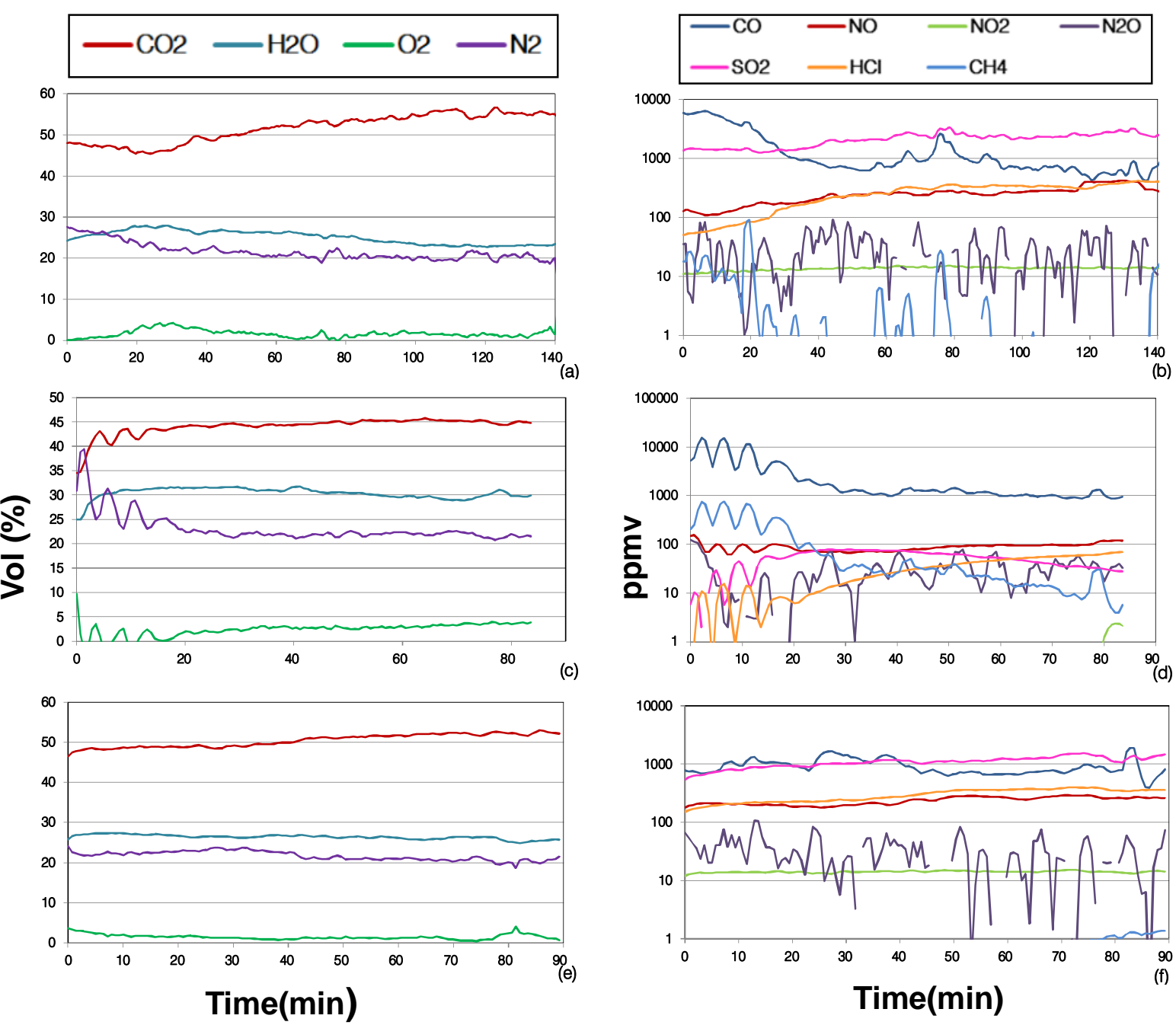

Fig. 3. Gas composition of the flue gas. (a) Main species 100\% Daw Mill. (b) Minor species 100\% Daw Mill. (c) Main species 100\% CCP. (d) Minor species 100\% CCP. (e) Main species 50\% Daw Mill- 50\% CCP. (f) Minor species 50\% Daw Mill- 50\% CCP. 
As expected, highest percentage of $\mathrm{CO}_{2}$ in the flue gas is achieved when $100 \%$ Daw Mill is burned. A summary of the maximum values for $\mathrm{CO}_{2}$ and average values for $\mathrm{H}_{2} \mathrm{O}, \mathrm{O}_{2}, \mathrm{SO}_{2}$ and $\mathrm{CO}$ reached is given in Table 2. These data are in qualitative agreement with typical gas composition obtained in different facilities by other authors (Steinmetz et al., 2011 ; Haykiri-Acma et al., 2010 ; Tai et al., 2011) as shown in Table 2. The quantitative effect that the amount of air ingress has on the decrease of the $\mathrm{CO}_{2}$ concentration follows the trend suggested by (Steinmetz et al., 2011). In the graph proposed by these authors an increment in the air ingress into the process of $1 \%$ causes a drop in the $\mathrm{CO}_{2}$ content of around $3.5 \%$. The main points where the air leakage takes place are believed to be in the recirculation fan and along the oxy-combustor. In reality, the same type of issues would probably be faced in retrofitting an existing power plant, so it is necessary to explore the effect of such leakage. In addition, such data are relevant to hybrid concepts, where oxy-fuel is combined with amine scrubbing (Huang et al., 2012).

Table 2: Experimental values for gas compositions in comparison with the other authors' results (Steinmetz et al., 2011 ; Haykiri-Acma et al., 2010 ; Tai et al., 2011)

\begin{tabular}{|c|c|c|c|c|c|c|c|c|c|c|c|}
\hline \multicolumn{6}{|c|}{ IERT, Cranfield University } & \multicolumn{2}{|c|}{$\begin{array}{c}\text { (Steinmetz et } \\
\text { al., 2011) }\end{array}$} & \multicolumn{2}{|c|}{$\begin{array}{c}\text { (Haykiri- } \\
\text { Acma et al., } \\
\text { 2010) }\end{array}$} & \multicolumn{2}{|c|}{$\begin{array}{c}\text { (Tai et al., } \\
\text { 2011) }\end{array}$} \\
\hline \multicolumn{2}{|c|}{$\begin{array}{l}\text { 100\% Daw } \\
\text { Mill Coal }\end{array}$} & \multicolumn{2}{|c|}{$\begin{array}{l}\text { 100\% CCP } \\
\text { Biomass }\end{array}$} & \multicolumn{2}{|c|}{$\begin{array}{l}50 \% \text { Daw } \\
\text { Mill-50\% } \\
\text { CCP Blend }\end{array}$} & \multicolumn{2}{|c|}{$\begin{array}{l}100 \% \text { Coal } \\
\text { (10\% air ingress) }\end{array}$} & \multicolumn{2}{|c|}{$\begin{array}{l}\text { Blends of } \\
\text { Coal and } \\
\text { Biomass } \\
\end{array}$} & \multicolumn{2}{|c|}{$100 \%$ Coal } \\
\hline wb & db & wb & $\mathrm{db}$ & wb & $\mathbf{d b}$ & wb & db & wb & db & wb & db \\
\hline 56.7 & 73.6 & 45.7 & 65.3 & 53 & 72 & 62.4 & -- & $55-65$ & 96 & 68 & 90 \\
\hline 23 & -- & 30 & -- & 26.4 & & 4.2 & -- & -- & -- & 20 & -- \\
\hline 1.5 & -- & 3 & -- & 1.5 & & 3 & -- & -- & -- & -- & -- \\
\hline 2000 & -- & 100 & -- & 1500 & & -- & -- & -- & -- & -- & -- \\
\hline 1000 & -- & 1200 & -- & 900 & & -- & -- & -- & -- & -- & -- \\
\hline
\end{tabular}

The content of $\mathrm{H}_{2} \mathrm{O}$ vapour measured in the flue gas increases when the content of biomass in the fuel is as expected is higher. Problems related to the performance of the FTIR analyser were observed during the test where $100 \%$ CCP was used and in the future a condenser will be placed between the cyclone and the recirculation fan as conditioning equipment for the RFG.

The measured $\mathrm{SO}_{2}$ concentration follows the trend of decreasing when the content of biomass in the fuel is higher. This was expected given that the biomass used here has one eighth the sulphur present in the coal used. However, while the case where co-firing $50 \%$ coal-50\% biomass shows a content of $\mathrm{SO}_{2}$ in the flue gas in agreement (same order of magnitude) with the theoretical prediction (1217 ppm measured against $1450 \mathrm{ppm}$ predicted), that is not the case for the test where $100 \%$ of biomass was oxy-fired. The decrease in the $\mathrm{SO}_{2}$ content when burning $100 \%$ cereal co-product is higher than expected (47 ppm measured against 320 ppm predicted). The most likely reason is that the FTIR analyser results were affected by the very high concentration of $\mathrm{H}_{2} \mathrm{O}$ vapour. An additional explanation for the $\mathrm{SO}_{2}$ content not following the expected trend may be that part of the $\mathrm{SO}_{2}$ was oxidized to $\mathrm{SO}_{3}$ and condensed together with the $\mathrm{H}_{2} \mathrm{O}$ vapour $\left(\mathrm{H}_{2} \mathrm{SO}_{4}\right)$. This may also be a consequence of the temperature dropping below the acid dew point in a particular location of the RFG pipeline. The CO presence is very high (around 10000 ppm) during the initial stage of the tests using either $100 \%$ Daw Mill or a $100 \%$ cereal co-product. But once the steady operation regime is reached, it drops down to around $850 \mathrm{ppm}$, on average (800 ppm for 100\% Daw Mill coal; 1000 ppm for $100 \%$ cereal co-product: 700 ppm for $50 \%$ coal- $50 \%$ biomass). It is possible that part of the explanation for this result is that the gaseous species are sampled inside the combustor and relatively close to the flame. As such the equilibrium of the exothermic reaction, $\mathrm{CO}+0.5 \mathrm{O}_{2} \leftrightarrow \mathrm{CO}_{2}$, would be shifted towards the generation of $\mathrm{CO}$ instead of $\mathrm{CO}_{2}$, due to the high temperatures and elevated $\mathrm{CO}_{2}(\mathrm{Chen}$ et al., 2012). The maximum flue gas temperatures reached during the experimental tests was achieved when oxy-firing $100 \%$ Daw Mill coal $\left(1100^{\circ} \mathrm{C}\right)$. The temperatures decrease as the content of biomass in the fuel increases, due to the lower heat value of this fuel. The $\mathrm{HCl}$ and $\mathrm{NO}$ contents decrease in the flue gas when there is more biomass in the fuel. In terms of ash sampling data, the appearance of the deposits generated using different types of fuel indicate that when using $100 \%$ CCP the structure of the deposit is more fibrous and porous than when oxy-firing $100 \%$ Daw Mill coal or the blend of 50\% Daw Mill-50\% CCP (see Fig. 4). Additionally, from the SEM images the larger size of the particles of the $100 \%$ CCP case is observed.
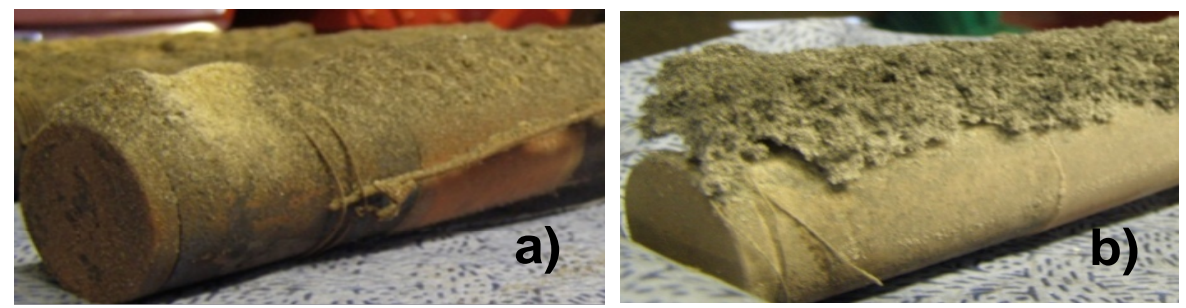
Fig. 4.: Close up view of the deposits formed from oxy-firing a) Daw Mill:CCP(50:50 \%,wt), b) $\operatorname{CCP}(100 \%$,wt).

Fig. 5 shows the elemental concentration (\%wt) of the ash generated during the oxy-combustion of different fuels (100\% Daw Mill coal, 100\% cereal co-product biomass, and 50\% Daw Mill coal-50\% cereal co-product biomass).

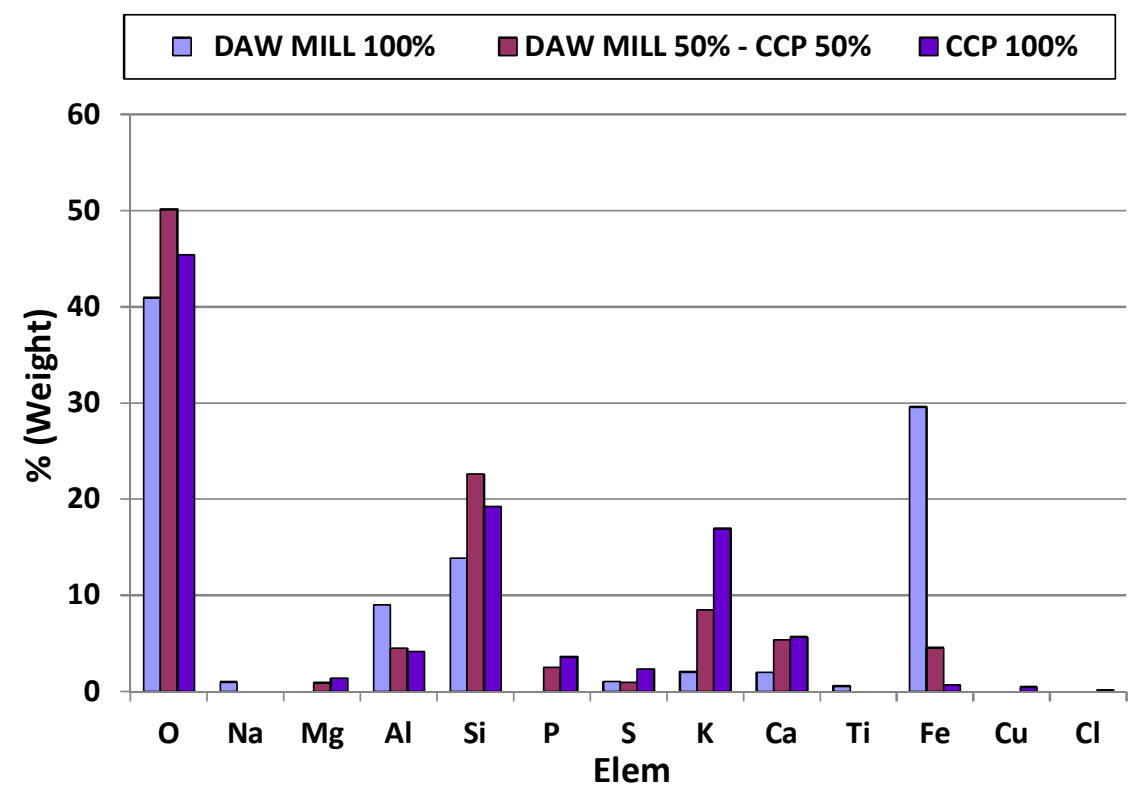

Fig. 5.: Elemental concentrations of the top deposits for different fuels.

For elements such as $\mathrm{K}, \mathrm{Mg}, \mathrm{Fe}$, and $\mathrm{Ti}$, the trend followed agrees with the previous analysis. It is worth mentioning that $\mathrm{K}$ and $\mathrm{Mg}$ increases with the percentage of biomass, and $\mathrm{Fe}$ and Ti rises with the percentage of coal. Other elements $(\mathrm{O}, \mathrm{Si})$ do not show a clear pattern and $\mathrm{Ca}$ content increases as the share of biomass increases, showing an opposite behaviour to that expected. The $S$ content in ash increases with the share of biomass in the fuel fired; contrary to expectations given that the elemental analysis of the parent fuels shown in Table 1 (the $S$ content in coal is eight times higher than in biomass). It is possible that this is due to the higher content of $\mathrm{K}$ in deposits generated from $100 \% \mathrm{CCP}$, as higher $\mathrm{K}$ in the fuel means more $\mathrm{K}_{2} \mathrm{SO}_{4}$ is likely to form. In addition, the lower temperatures experienced in the reactor may possibly have increased the conversion from $\mathrm{SO}_{2}$ to $\mathrm{SO}_{3}$ compared to cases using coal or co-firing (Ahn et al., 2011). However, the resulting trend for the $S$ content in ash is not very different from the one shown by Stanger and Wall (Stanger and Wall, 2011), where coals with low S-content $(0.24 \%$, db) generated ash with similar $\mathrm{SO}_{3}$ content to the ash from oxy-firing higher S-content coals $(0.88 \%$, db).

$\mathrm{Cl}$ content was only detected in the deposits generated when oxy-firing $100 \%$ CCP biomass. This, together with the higher concentration of $\mathrm{HCl}$ in the flue gas generated by $100 \%$ coal, and $50 \%$ coal-50\% biomass (also reported by Khodier and Simms, 2010), indicates that $\mathrm{Cl}$ tends to be in the gaseous phase and not retained in the ash deposit when there is a low share of biomass in the fuel.

\section{Simulation Results and Comparison with Experimental Data}

To carry out the comparison between the simulation and the experimental data, key parameters such as amount of air ingress into the process, $\% R F G$, and $\% \mathrm{O}_{2}$ excess in the comburent stream have been varied within a range to recreate the same operating conditions as in the experimental tests. The experimental data used to validate the rate-based simulation model were generated at the retrofitted Cranfield University oxycombustor. Each of the parameters varied for the simulations was changed while keeping a fixed value for the rest. The first phase of the rate-based simulations was focused on the study of the effects when the percentage of air ingress varied $(2 \%, 10 \%$ and $18 \%$ of the total flow rate fed to the oxy-combustor), and the selection of the amount of air ingress that better represented the experimental conditions during the operation of the pilot plant. Fig. 6 shows the comparison between the experimental data and the results from the intermediate rate-based simulation model (box-plot shown in Fig. 2).

For these simulations 55\% RFG was used, and two different excess $\mathrm{O}_{2}$ feed values (0 and 5\%). The $\mathrm{CO}_{2}$ percentage is better predicted by the simulations that used $2 \%$ and $10 \%$ of air ingress. For the simulation case for $18 \%$ of air ingress, the flue gas appears to be more diluted than in the experimental cases. Regarding the $\mathrm{H}_{2} \mathrm{O}$ vapour content, there is a better estimation for the $18 \%$ air ingress case, using $100 \%$ CCP as fuel. For the $\mathrm{O}_{2}$ percentage at the exit of the oxy-combustor, the simulations using 2 and $10 \%$ of air ingress give a good approximation in comparison with the experimental data. Consequently, supplementary simulations to improve the rate-based model will be done using $10 \%$ air ingress. 


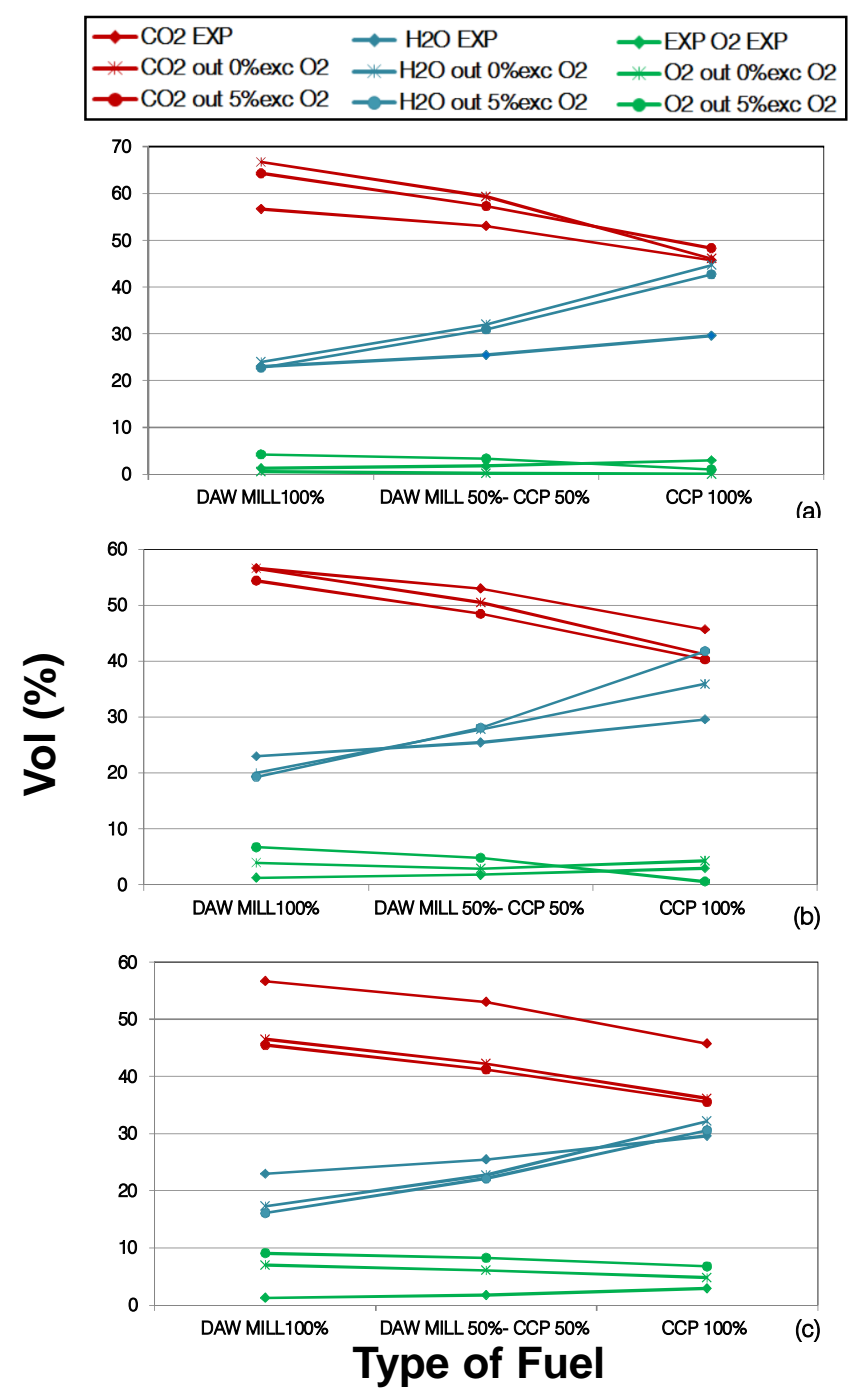

Fig. 6.: Comparison between experimental data and results from rated-based simulations using different percentages of air ingress. (a) $2 \%$ Air ingress. (b) $10 \%$ Air ingress. (c) $18 \%$ Air ingress.

The temperature estimation given by the model is in good agreement with the measurements of (Smart et al., 2010b), for a $500 \mathrm{MW}$ th test rig. Likewise, these calculations were checked using the FACT program, allowing for flame dissociation and gave very similar results to the ASPEN calculation (T Aspen:1940ㄷ against T FACT:1944 ${ }^{\circ} \mathrm{C}$ [results generated using 100\% Daw Mill coal as fuel, feeding $5 \%$ of excess of oxygen over the stoichiometric, and recirculating $55 \%$ of the flue gas to the oxy-combustor block]). It should be noted that, given that temperatures are at or below $2000 \mathrm{~K}$, and so dissociation has been ignored in the ASPEN simulation.

\section{CONCLUSION AND FUTURE WORKS}

This paper summarises the experimental work carried out in the retrofitted $100 \mathrm{~kW}$ oxy-combustor located at Cranfield University in the UK, as well as the rate-based simulation model designed using Aspen Plus $\AA^{\circledR}$. The fuels used for this study have been 100\% Daw Mill Coal, 50\% Daw Mill Coal-50\% cereal co-product and 100\% cereal coproduct biomass. The performance of the combustor was studied, keeping recirculation of the flue gas around $52 \%$, and the maximum percentage of $\mathrm{CO}_{2}$ achieved was $56.7 \%$, wb $(73.6 \%$, db) when $100 \%$ Daw Mill Coal was fired. The high content of $\mathrm{H}_{2} \mathrm{O}$ vapour in the flue gas when firing $100 \%$ cereal co-product biomass caused operational complications. Thus a water condenser will be installed as part of the flue gas conditioning equipment with the aim of avoiding these difficulties in forthcoming tests. The air ingress into the process was calculated to be about $10 \%$ of the total gas fed to the chamber.

The ash deposition was evaluated taking into account different fuels and it was appears that similar sulphate contents existed in deposits generated using 100\% Daw Mill coal and 100\% cereal co-product, even though the biomass has much lower $\mathrm{S}$ content in its elemental analysis. The higher $\mathrm{K}$ content in the deposits generated by oxyfiring of $100 \%$ cereal co-product biomass was also noticeable. Consequently, operational problems, related to materials corrosion, are likely to occur due to. In general the oxy-fuel environment appears to be more "corrosive" in comparison to the air-firing environment due to higher levels $\mathrm{K}_{2} \mathrm{SO}_{4}$ formation in the deposits as well as the higher $\mathrm{SO}_{\mathrm{x}}$ content in the flue gas generated in the oxy-combustion process. Also higher concentrations of $\mathrm{K}$ and $\mathrm{Cl}$ in the deposits generated by $100 \%$ cereal co-product biomass suggest the formation of $\mathrm{KCl}$, which would contribute to 
more corrosion problems as it is a highly fouling compound. Further corrosion research is required to study this effect in more detail.

A kinetic simulation model was developed and validated to determine the amount of air ingress in comparison with the experimental data. It was estimated that the air ingress into the reactor is $10 \%$ of the total gas fed to the combustor. Simulation results using different values for \% RFG and \% $\mathrm{O}_{2}$ excess fed to the oxy-combustor are achieved. In the second stage a rate-based model with partial condensation in the RFG is under development.

\section{Acknowledgments}

The authors would like to thank the UK Engineering and Physical Sciences Research Council (EPSRC) and EON to the Oxy-Cap UK consortium for their financial support. The authors also acknowledge Dr. Jinsheng Wang from Canmet Energy for his help with FACT simulations.

\section{REFERENCES}

Ahn, J., Okerlund, R., Fry, A. and Eddings, E. G. (2011), "Sulfur trioxide formation during oxy-coal combustion", International Journal of Greenhouse Gas Control, vol. 5, Supplement 1, no. 0, pp. S127-S135.

Arias, B., Pevida, C., Rubiera, F. and Pis, J. J. (2008), "Effect of biomass blending on coal ignition and burnout during oxy-fuel combustion", Fuel, vol. 87, no. 12, pp. 2753-2759.

Borrego, A. G., Garavaglia, L. and Kalkreuth, W. D. (2009), "Characteristics of high heating rate biomass chars prepared under N2 and CO2 atmospheres", International Journal of Coal Geology, vol. 77, no. 3-4, pp. 409-415.

Chen, L., Yong, S. Z. and Ghoniem, A. F. (2012), "Oxy-fuel combustion of pulverized coal: Characterization, fundamentals, stabilization and CFD modeling", Progress in Energy and Combustion Science, vol. 38, no. 2, pp. 156-214.

Corsten, M., Ramírez, A., Shen, L., Koornneef, J. and Faaij, A. (2013), "Environmental impact assessment of CCS chains - Lessons learned and limitations from LCA literature", International Journal of Greenhouse Gas Control, vol. 13, no. 0, pp. 59-71.

Edge, P., Gharebaghi, M., Irons, R., Porter, R., Porter, R. T. J., Pourkashanian, M., Smith, D., Stephenson, P. and Williams, A. (2011), "Combustion modelling opportunities and challenges for oxy-coal carbon capture technology", Chemical Engineering Research and Design, vol. 89, no. 9, pp. 1470-1493.

Field, M. A. (1969), "Rate of combustion of size-graded fractions of char from a low-rank coal between 1 $200^{\circ} \mathrm{K}$ and $2000^{\circ} \mathrm{K} "$, Combustion and Flame, vol. 13, no. 3, pp. 237-252.

Haykiri-Acma, H., Turan, A. Z., Yaman, S. and Kucukbayrak, S. (2010), "Controlling the excess heat from oxy-combustion of coal by blending with biomass", Fuel Processing Technology, vol. 91, no. 11, pp. 15691575.

$\mathrm{Hu}, \mathrm{Y}$. and Yan, J. (2012), "Characterization of flue gas in oxy-coal combustion processes for CO2 capture", Applied Energy, vol. 90, no. 1, pp. 113-121.

Huang, Y., Wang, M., Stephenson, P., Rezvani, S., Mcllveen-Wright, D., Minchener, A., Hewitt, N., Dave, A. and Fleche, A. (2012), "Hybrid coal-fired power plants with CO2 capture: A technical and economic evaluation based on computational simulations", Fuel, vol. 101, no. 0, pp. 244-253.

Khodier, A. and Simms, N. (2010), "Investigation of gaseous emissions and ash deposition in a pilot-scale PF combustor co-firing cereal co-product biomass with coal. Conference on Renewable Energies and Power Quality, 2010.", Conference on Renewable Energies and Power Quality, 2010. .

Murphy, J. J. and Shaddix, C. R. (2006), "Combustion kinetics of coal chars in oxygen-enriched environments", Combustion and Flame, vol. 144, no. 4, pp. 710-729.

Smart, J. P., Patel, R. and Riley, G. S. (2010a), "Oxy-fuel combustion of coal and biomass, the effect on radiative and convective heat transfer and burnout", Combustion and Flame, vol. 157, no. 12, pp. 22302240.

Smart, J., Lu, G., Yan, Y. and Riley, G. (2010b), "Characterisation of an oxy-coal flame through digital imaging", Combustion and Flame, vol. 157, no. 6, pp. 1132-1139.

Sotudeh-Gharebaagh, R., Legros, R., Chaouki, J. and Paris, J. (1998), "Simulation of circulating fluidized bed reactors using ASPEN PLUS", Fuel, vol. 77, no. 4, pp. 327-337.

Stanger, R. and Wall, T. (2011), "Sulphur impacts during pulverised coal combustion in oxy-fuel technology for carbon capture and storage", Progress in Energy and Combustion Science, vol. 37, no. 1, pp. 69-88. 
Steinmetz, C., Bergins, C., Weckes, P. and Dieter, K. (2011), " Oxyfuel Power Plant Design: Retrofit Options for Different Fuels.", 2nd Oxyfuel Combustion Conference, Vol. 1, $12-16$ September, Queensland, Australia, IEAGHG, UK, .

Tai, Z., Zhaohui, L., Xiaohong, H., Jingzhang, L., Dingbang, W. and Chuguang, Z. (2011), " O2 / RFG Coal Combustion Results on a 300kW Pilot Scale Facility", 2nd Oxyfuel Combustion Conference, 12-16 September, Queensland, Australia, IEAGHG, UK, .

Toftegaard, M. B., Brix, J., Jensen, P. A., Glarborg, P. and Jensen, A. D. (2010), "Oxy-fuel combustion of solid fuels", Progress in Energy and Combustion Science, vol. 36, no. 5, pp. 581-625.

Wall, T., Liu, Y., Spero, C., Elliott, L., Khare, S., Rathnam, R., Zeenathal, F., Moghtaderi, B., Buhre, B., Sheng, C., Gupta, R., Yamada, T., Makino, K. and Yu, J. (2009), "An overview on oxyfuel coal combustion-State of the art research and technology development", Chemical Engineering Research and Design, vol. 87, no. 8, pp. 1003-1016.

Xiong, J., Zhao, H., Chen, M. and Zheng, C. (2011), "Simulation Study of an 800 MWeOxy-combustion Pulverized-Coal-Fired Power Plant", Energy \& Fuels, vol. 15, pp. 2405. 